\title{
Long-term hydraulic behaviour and soil ripening processes in a dike constructed from dredged material
}

\author{
Julia Gebert ${ }^{1}\left[\right.$ : $\cdot$ Alexander Groengroeft ${ }^{2}$
}

Received: 15 May 2019 / Accepted: 3 December 2019/Published online: 17 December 2019

(C) The Author(s) 2019

\begin{abstract}
Purpose Climate change necessitates heightening and strengthening of dikes, requiring large volumes of suitable soil. This study investigated soil ripening and long-term development of hydraulic behaviour of a dike constructed from slightly contaminated, partially dewatered dredged material from the Port of Hamburg under realistic conditions of construction and operation.

Materials and methods Two test fields of $126 \mathrm{~m}^{2}$ each were constructed in 2004 for long-term analysis of hydraulic behaviour in combination with the possible mobilisation of contaminants. In test field 1 (MS), the 1-m-thick cover above the sand core consisted of traditionally used alluvial marsh sediment (reference), while in test field 2, the lower $0.7 \mathrm{~m}$ of the cover was substituted with dredged material (DM + MS). An HDPE tray below each field served the collection of bottom fluxes and hence the quantification of discharges and analysis of their chemical composition. In 2012, an excavation was carried out to inspect the development of the soil structure.

Results and discussion The discharge pattern revealed three distinct phases related to the post-construction structure development and therefore physical ripening of the soils. Within a single year, bottom fluxes typically started in mid-winter and ended in late spring. The dike cover containing DM had a high water retention capacity; however, the vertically continuous primary shrinkage cracks led to higher total bottom fluxes compared to the dike constructed from MS only. System hydraulic conductivities increased by up to six orders of magnitude compared to the as-built condition before soil ripening and structuring. The dredged material maintained a reduced geochemical status for about two years after construction. After first shrinkage and intrusion of oxygen, the material changed to an oxidised state, earmarking the onset of the chemical ripening process. Oxidising conditions were sustained in the long term, seen from the absence of previously elevated ammonium concentrations in the dike seepage. Conclusions System hydraulics of the test field with dredged material were mainly determined by the covering layer of marsh sediment. After construction, the dredged material underwent physical, chemical and biological soil ripening processes, coupled to a respective change in discharge patterns, which, however, did not impair dike stability. It is recommended that soil ripening processes are induced and completed as part of the material's pre-treatment, precluding the formation of irreversible shrinkage cracks and changeover of redox conditions after construction. The findings contribute to assessing the feasibility of the beneficial use of dredged material.
\end{abstract}

Keywords Beneficial use $\cdot$ Dikes and embankments $\cdot$ Sediment $\cdot$ Soil ripening $\cdot$ Soil structure

\section{Introduction}

Responsible editor: Victor Magar

Julia Gebert

j.gebert@tudelft.nl

1 Department of Geoscience \& Engineering, Delft University of Technology, Stevinweg 1, 2628 CN Delft, The Netherlands

2 Institute of Soil Science, University of Hamburg, Allende-Platz 2, 20146 Hamburg, Germany
Dikes constructed from earthen materials are key elements of primary flood protection along rivers and coastlines. Cross sections for coastal dikes and river dikes vary, but modern dikes all share a core of sand, covered by a layer of finegrained, clay-rich material. The cover serves to protect the core against wave action, to reduce the infiltration rate and to provide a suitable substrate for a dense grass vegetation, protecting the dike from erosion. If a dike foreland is absent, a layer of crushed rocks is often placed at the slope toe to 
dissipate the wave energy. Individual dike components must meet specific requirements, which may vary by country (Ausschuss für Küstenschutzwerke 2002; DWA 2005; both for Germany). For the construction of the outer cover layer, fine-grained alluvial marsh sediment is the typical substrate used in north-western Germany. The exploitation of these soils can conflict with the predominant agricultural use and other aims of land use planning and soil protection in the marsh areas. However, both the rise of mean sea level induced by climate change and natural and anthropogenic land subsidence necessitate heightening and strengthening of dikes and embankments, hence requiring increased amounts of construction material in the near future. At the same time, far over 100 million $\mathrm{m}^{3}$ of sediment are dredged annually in Europe alone (Bortone and Palumbo 2007; OSPAR 2016) to sustain the nautically required depth of fairways and harbour basins, a share of which comes on land for further treatment, and disposal or recovery.

Dredged material is increasingly viewed as a resource rather than a waste (CEDA 2019), and in light of efforts towards a circular economy, different options for its beneficial use are investigated. Examples are the partial substitution of raw material in brick production (Cappuyns et al. 2015), construction of mineral liners (Tresselt 2000; LAGA 2008; Berger et al. 2019) and profiling layers or the backfilling of harbour basins (Gutbrod 2016). Baptist et al. (2019) investigated the use of dredged material to stimulate accretion of sediment in order to enhance salt marsh development. The suitability of uncontaminated dredged material from the Baltic Sea for dike construction has been successfully proven in a full-scale field experiment (Saathoff et al. 2013). The 'Kleirijperij' experimental site (https://www.ecoshape.org/nl/projecten/kleirijperij/) currently investigates how earthen, soil-like material for the construction of dikes can be produced from dredged sediment from the Eems-Dollard. In a different approach, beneficial use of dredged sediment is currently being demonstrated by the Marker Wadden project (https://www.ecoshape.org/nl/ projecten/marker-wadden-2/) in which material from the Dutch Markermeer is used to create habitats and spawning areas for fish and avifauna by forming islands, banks and shallow-water zones.

In Germany's largest port, the Port of Hamburg, several million metric tons of dredged material are contracted annually, of which most is relocated downstream within the River Elbe or to the North Sea. Owing to a legacy of industrial and mining activities in the upstream region as well as in Hamburg itself, a smaller part of the dredged sediment shows contaminant concentrations that exceed the level permitted for relocation of the material within the river. This portion is brought to land where it is separated according to particle size and dewatered in the METHA plant (Detzner et al. 1997) and disposed of in mono-landfills, representing the largest single waste stream of the city of Hamburg. The ease with which the material can be applied in earthen construction using standard machinery and its low hydraulic conductivity enabled beneficial use as mineral liner material (Berger et al. 2019) and motivated researching the possible application in dike construction. In 2004, a long-term full-scale field test was initiated to investigate (1) the hydraulic behaviour and (2) the possible mobilization and emission of contaminants of a dike section constructed from dredged material (DM) in comparison to a dike section constructed from the traditionally used marsh sediments (MS). This paper describes the long-term development of bottom fluxes and the corresponding composition of leachate. In combination, these allow for conclusions on physical, chemical and biological transformation processes, also referred to as soil ripening, occurring in the dredged material after construction.

\section{Design of test cells and monitoring program}

The test cells were integrated into a dam closing off a backfilled harbour basin against the river Elbe in the Port of Hamburg. The area is subject to a mean tidal range of $3.66 \mathrm{~m}$. Construction commenced in August 2004. After preparation and profiling of the underlying substratum, the liner, pipes and the so-called collection shaft and the drainage shaft (all high density polyethylene, HDPE, containing equipment for quantification of discharges) were constructed, followed by the layered construction of the test cell soil substrates. Test cell 1 was constructed completely from traditionally used marsh sediment (alluvial material rich in clay) and served as a control setup. Test cell 2 consisted of $70 \mathrm{~cm}$ of dredged material treated in the METHA plant, overlain by $30 \mathrm{~cm}$ of marsh sediment (Fig. 1). The first $70 \mathrm{~cm}$ was constructed in three layers, the top $30 \mathrm{~cm}$ in one single pass. To prevent interface effects, the top $5 \mathrm{~cm}$ of each layer was scraped off before placement of the subsequent layer. Following the distribution of the material with an excavator, each layer was compacted three times using a roller and then sampled for analysis of soil physical properties. Finally, the technical equipment for monitoring drainage quantity and quality was installed in the collection shaft and the drainage shaft. The surface was seeded with a standard grass mixture. Test cell base area dimensions were $9 \mathrm{~m} \times$ $14 \mathrm{~m}$, total height was $1 \mathrm{~m}$ and the slope was 1:3. An aerial view of the setup is given in Fig. 2.

Test cell leachate collected via the HDPE membrane accumulated in the collection shaft (HDPE) located at the base of the dam between the two test cells. The shaft contained a dividing wall for separate collection of the leachate from the two test cells. The volume of generated leachate was monitored automatically by water level loggers (type PLog520PAINT, Driesen + Kern Ltd) placed in the two sections of the shaft; data were recorded every $15 \mathrm{~min}$. When a level of $80 \mathrm{~cm}$ was reached (detected by fill level point setter, type Liquipoint 
Fig. 1 Schematic cross section of test cell $2 . \mathrm{msl}=$ mean sea level

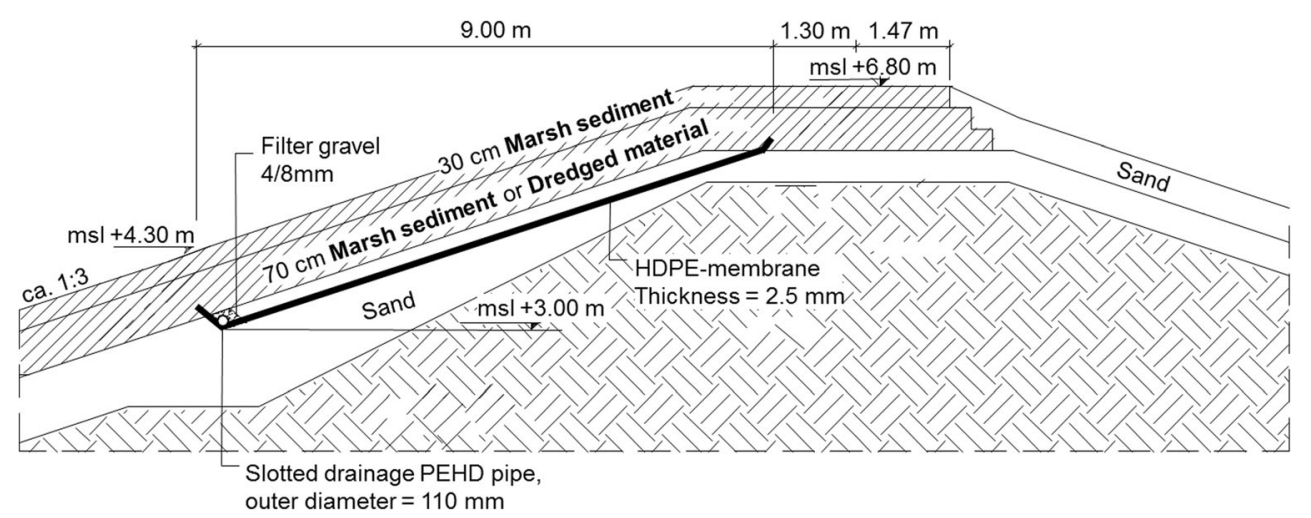

T FTW 31/32, Endress + Hauser Ltd), the leachate was pumped into the upslope drainage shaft (pump Ama-Drainer 303.1, KSB Ltd). Each pumping process emptied the corresponding section of the collection shaft by 2261 . In the drainage shaft, the pump discharge was quantified by automated magnetic-inductive flow meters (type promag 520, Endress + Hauser Ltd). Hence, two independent measurements of bottom fluxes were obtained. Air temperature, humidity and precipitation were monitored with an on-site climate station (type Combilog, THEODOR FRIEDRICHS Ltd). Bi-weekly to monthly, leachate samples were collected from siphons installed in the collection shaft and analysed for inorganic and organic components.

Between 2012 and 2015, soil moisture content was measured manually on 120 dates using a time domain reflectometry (TDR) probe (IMKO, type T3/44), for which the shafts were installed permanently in downslope and upslope positions per test field, just outside of the actual test field area. Measurements were carried out in depth intervals of $10 \mathrm{~cm}$ and data aggregated for the following depths: $0-30 \mathrm{~cm}, 30$ $60 \mathrm{~cm}$ and $60-100 \mathrm{~cm}$ below surface.

\section{Sample collection and laboratory analytical methods}

Undisturbed samples were collected from the middle part of all constructed layers and analysed for water content (DIN ISO 11465), bulk density, water retention curve (DIN ISO 11274) and saturated hydraulic conductivity (DIN 18130, DIN 19683-9). Additionally, mixed disturbed samples of all materials, collected during excavation of the undisturbed samples from the same depth, were tested for particle size distribution (DIN ISO 11277), moisture-density relationship (Proctor test, DIN 18127), organic carbon content (DIN ISO 10694) and pH (DIN ISO 10390). Contaminants were analysed according to DIN ISO 11466 (metals), DIN ISO 10382 (PCB) and DIN 19744 (organotin compounds). The sand drainage layer was only sampled once, in test cell 2 .

Eluates were prepared according to the DEV-S4 protocol (DIN 38414-4). Eluate analyses followed DIN 38404-C5 9 (pH), DIN EN 2788-C8 (electric conductivity), DIN EN ISO 10304-1/2-D19/20 (chloride, sulphate), DIN 38406-E29 and
Fig. 2 Aerial view of the field experimental setup; not to scale

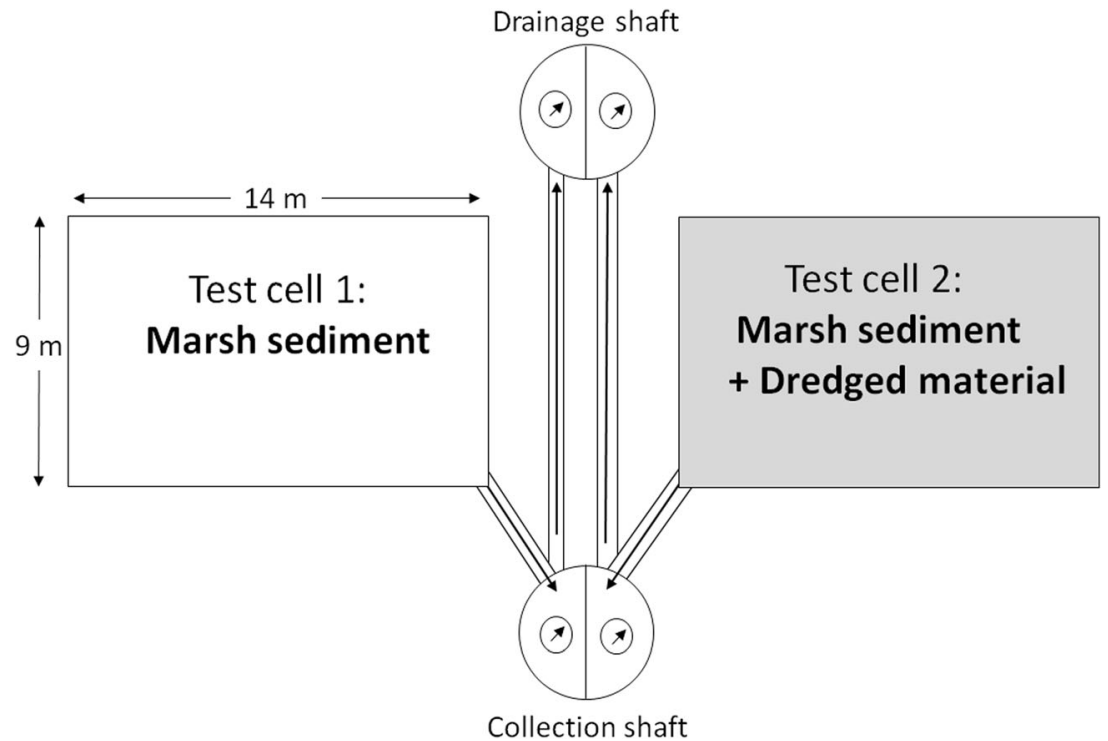


DIN ISO 11466 (metals), DIN EN ISO 11732-E23 (ammonium) and EN ISO 6468-F1 (PCB).

\section{Material properties}

\subsection{Physical properties}

Tables 1 and 2 summarise the soil physical characteristics of the individual layers of the marsh sediment and the dredged material; the water retention curves are shown in Fig. 3. Both the dredged material and the marsh sediment layers were very homogeneous with respect to their texture. In test cell 1 (purely marsh sediment), only the top layer was coarser than the materials from the deeper layers, resulting in a classification as silt loam instead of silty clay loam (FAO 2006). Compared to the dredged material, the marsh sediment was characterised by a high clay content (approx. $40 \%$ by weight compared to $20 \%$ in the dredged material) and by a higher silt content ( $45 \%$ vs. $30 \%$ ). Correspondingly, the sand fraction was larger in the dredged material (45\% vs. $15 \%$ ) (Table 1 ).

In accordance with its higher clay content, the marsh sediment was characterised by a high share of water bound in the pores $<0.2 \mu \mathrm{m}$ (corresponding to a water potential of $>$ $15.000 \mathrm{hPa}$ or $\mathrm{pF}>4.2$; see Fig. 3), which is considered not to be plant available. These pores comprise approximately $80 \%$ of the total pore volume, compared to only $45 \%$ in the dredged material. At field capacity (i.e. at maximum water retention against gravity, corresponding to a water potential of $60 \mathrm{hPa}$ or $\mathrm{pF} 1.8$ ), the water content amounted to an average of 51 vol.- $\%$ for the marsh sediment and of 60 vol.- $\%$ for the dredged material. Plant-available water, bound in the pores of $0.2-50 \mu \mathrm{m}$ (corresponding to a water potential of $60 \mathrm{hPa}$ to $15,000 \mathrm{hPa}$ ), was calculated with an average of $127 \mathrm{~m}^{-2}$ for the marsh sediment and $2821 \mathrm{~m}^{-2}$ for the dredged material for a 1-m-thick layer.

In line with the pore size distribution, the mean bulk density of the dredged material layers was relatively low at $0.95 \mathrm{~g} \mathrm{~cm}^{-3}$ compared to $1.41 \mathrm{~g} \mathrm{~cm}^{-3}$ for the layers constructed from fine-grained marsh sediments (Table 3 ). An additional difference was found in the amount of organic carbon, which ranged from 3.3 to 6.0 mass- $\%$ for the dredged material and from 2.0 to 2.1 mass- $\%$ for the marsh sediments at the time of construction. The hydraulic conductivity of the dredged material as put in place corresponds to the values previously determined by Tresselt (2000) for a mineral landfill top liner constructed from dredged material and was around one order of magnitude higher than that of the clayey marsh sediment.

\subsection{Chemical properties}

In comparison to the marsh sediment, the treated dredged material (Table 4) features twice or more than twice the amount of sulphur, organic carbon nitrogen, a significantly higher electric

Table 1 Particle size distribution of test cell materials, given in weight- $\%$

\begin{tabular}{|c|c|c|c|c|c|c|c|c|c|c|}
\hline $\begin{array}{l}\text { Test cell } \\
\text { Grain siz }\end{array}$ & $\begin{array}{l}\text { Depth }(\mathrm{cm}) \\
\mathrm{e}(\mu \mathrm{m})\end{array}$ & Substrate & $\begin{array}{l}\text { Clay } \\
<2\end{array}$ & $\begin{array}{l}\text { Fine silt } \\
2-6.3\end{array}$ & $\begin{array}{l}\text { Medium silt } \\
6.3-20\end{array}$ & $\begin{array}{l}\text { Coarse silt } \\
20-63\end{array}$ & $\begin{array}{l}\text { Fine sand } \\
63-200\end{array}$ & $\begin{array}{l}\text { Medium sand } \\
200-630\end{array}$ & $\begin{array}{l}\text { Coarse sand } \\
630-2000\end{array}$ & $\begin{array}{l}\text { Soil texture class } \\
\text { AG Boden }(2005) * \text { FAO }(2006)\end{array}$ \\
\hline \multirow[t]{5}{*}{1} & $9-21$ & MS & 25.4 & 6.3 & 13.4 & 37.3 & 14.2 & 2.4 & 1.0 & $\begin{array}{l}\text { Silty loam (Lu) } \\
\text { *Silt loam (SiL) }\end{array}$ \\
\hline & $32-44$ & MS & 38.2 & 11.1 & 17.6 & 18.8 & 6.4 & 5.9 & 2.0 & $\begin{array}{l}\text { Medium clayey loam }(\mathrm{Lt} 3) \\
* \text { Silty clay loam }(\mathrm{SiCL})\end{array}$ \\
\hline & $54-66$ & MS & 35.7 & 11.7 & 17.9 & 21.1 & 7.4 & 4.7 & 1.4 & $\begin{array}{l}\text { Weakly clayey loam }(\mathrm{Lt} 2) \\
* \text { Silty clay loam }(\mathrm{SiCL})\end{array}$ \\
\hline & 79-91 & MS & 38.8 & 13.2 & 18.0 & 19.1 & 5.5 & 4.2 & 1.2 & $\begin{array}{l}\text { Medium clayey loam (Lt3) } \\
* \text { Silty clay loam }(\mathrm{SiCL})\end{array}$ \\
\hline & $105-115$ & Sand & 0.3 & 0.2 & 0.3 & 0.22 & 50.1 & 45.1 & 3.8 & $\begin{array}{l}\text { Fine sand (fSms) } \\
\text { *Fine sand (FS) }\end{array}$ \\
\hline \multirow[t]{5}{*}{2} & $9-21$ & MS & 20.2 & 4.9 & 11.3 & 44.8 & 15.5 & 2.4 & 0.8 & $\begin{array}{l}\text { Silty loam (Lu) } \\
\text { *Silt loam (SiL) }\end{array}$ \\
\hline & $32-44$ & $\mathrm{DM}$ & 20.9 & 4.8 & 9.2 & 22.2 & 37.5 & 4.8 & 0.6 & $\begin{array}{l}\text { Medium sandy loam Ls3 } \\
\text { *Loam (L) }\end{array}$ \\
\hline & $54-66$ & DM & 18.3 & 9.2 & 8.3 & 20.0 & 40.4 & 3.7 & 0.3 & $\begin{array}{l}\text { Medium sandy loam (Ls3) } \\
\text { *Loam (L) }\end{array}$ \\
\hline & 79-91 & DM & 19.2 & 10.0 & 4.5 & 23.2 & 38.7 & 3.8 & 0.5 & $\begin{array}{l}\text { Medium sandy loam (Ls3) } \\
\text { *Loam (L) }\end{array}$ \\
\hline & $105-115$ & Sand & 0.3 & 0.2 & 0.3 & 0.22 & 50.1 & 45.1 & 3.8 & $\begin{array}{l}\text { Fine sand (fSms) } \\
\text { *Fine sand (FS) }\end{array}$ \\
\hline
\end{tabular}

$M S$ marsh sediment, $D M$ dredged material 
Table 2 Bulk density and pore size distribution at the time of construction, derived from the water retention curves (Fig. 2)

\begin{tabular}{|c|c|c|c|c|c|c|c|}
\hline Test cell & Depth b.s. (cm) & Substrate & Total porosity (\%) & $<0.2 \mu \mathrm{m}(\%)$ & $0.2-10 \mu \mathrm{m}(\%)$ & $10-50 \mu \mathrm{m}(\%)$ & $>50 \mu \mathrm{m}(\%)$ \\
\hline \multirow[t]{5}{*}{1} & 15 & MS & 48.9 & 33.1 & 11.5 & 1.1 & 3.1 \\
\hline & 38 & MS & 53.2 & 38.9 & 11.6 & 1.4 & 1.3 \\
\hline & 60 & MS & 56.1 & 36.1 & 15.9 & 1.1 & 3.0 \\
\hline & 85 & MS & 54.1 & 42.3 & 7.3 & 0.8 & 3.8 \\
\hline & 110 & Sand & 46.1 & 1.0 & 12.9 & 19.3 & 23.3 \\
\hline \multirow[t]{5}{*}{2} & 15 & MS & 48.0 & 28.9 & 22.1 & 2.6 & 3.7 \\
\hline & 38 & $\mathrm{DM}$ & 64.0 & 34.0 & 26.7 & 3.3 & 4.6 \\
\hline & 60 & $\mathrm{DM}$ & 63.8 & 28.4 & 26.8 & 3.5 & 5.3 \\
\hline & 85 & $\mathrm{DM}$ & 62.5 & 28.4 & 26.8 & 2.2 & 5.1 \\
\hline & 110 & Sand & 46.1 & 1.0 & 12.9 & 19.3 & 23.3 \\
\hline
\end{tabular}

Depth refers to middle of sampling cylinder

$M S$ marsh sediment, $D M$ dredged material, b.s. below surface

conductivity (representative of the concentration of soluble salts) and an increased concentration (greater than factor 3) of selected metals $(\mathrm{Pb}, \mathrm{Cd}, \mathrm{Cu}, \mathrm{Zn}, \mathrm{Hg})$ and some organic contaminants (tributyltin from anti-fouling agents on ships, $\mathrm{PCB}_{7}$, $\mathrm{PAH}$ and hydrocarbons; not all data shown). With respect to the eluate, the dredged material shows a higher electric conductivity, owing to the high sulphate content in the eluate, and higher contents in $\mathrm{As}, \mathrm{Cd}$ and $\mathrm{Zn}$.

\section{Results}

This section presents the bottom fluxes from the two test cells (Section 5.1), analysed for conditions of normal load (precipitation only) and under conditions of increased hydraulic load (storm tide events). Further, the evolution of leachate composition (Section 5.2) over time is shown using selected redoxsensitive parameters (such as ammonium and iron) as well as inert parameters suitable to trace the displacement of porewater with water from precipitation. The combination of hydraulic data with leachate composition allows conclusion on processes of soil structuring, which was investigated by an excavation (Section 5.3).

\subsection{Hydraulic performance}

\subsubsection{Bottom fluxes}

Figure 4 shows the cumulated bottom flux for both test cells from the construction in 2004 to December 2015, i.e. for 11 years. The course of leachate generation of both test cells can be separated into three phases:

1. The first phase started with the construction and ended 2 years later (end of 2006). This phase was characterised by zero (test cell 1) or very low (test cell 2 ) bottom flux.

2. In the second phase (end of 2006 to summer 2008), the seepage rate increased strongly for test cell 2 (total leachate volume $=710 \mathrm{~mm}$ in 2 years). The seepage rate of test cell 1 also increased significantly, but only to the level of the years thereafter.
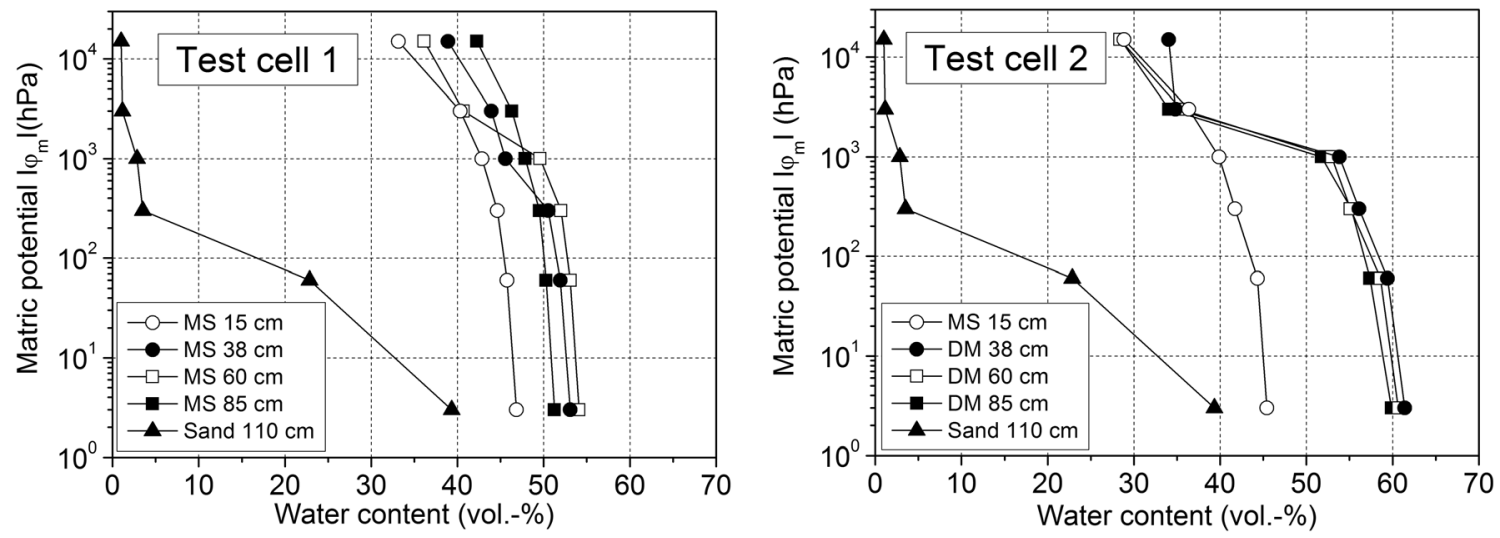

Fig. 3 Water retention curves of test cell materials at the time of construction. Points = average from 5 (sand) to 22 (MS, DM) parallels 
Table 3 Bulk density, water content and saturated hydraulic conductivity at the time of construction

\begin{tabular}{llllll}
\hline $\begin{array}{l}\text { Test } \\
\text { cell }\end{array}$ & $\begin{array}{l}\text { Depth b.s. } \\
(\mathrm{cm})\end{array}$ & Substrate & $\begin{array}{l}\text { Bulk density } \\
\left(\mathrm{g} \mathrm{cm}^{-3}\right)\end{array}$ & $\begin{array}{l}\text { Water content }(\% \\
\text { ww })\end{array}$ & $\begin{array}{l}\text { Hydraulic conductivity } \\
\left(\mathrm{m} \mathrm{s}^{-1}\right)\end{array}$ \\
\hline 1 & 15 & MS & 1.34 & 45.6 & $2.73 \times 10^{-10}$ \\
& 38 & MS & 1.19 & 50.2 & $2.52 \times 10^{-10}$ \\
& 60 & MS & 1.15 & 51.6 & - \\
& 85 & MS & 1.21 & 56.7 & $3.20 \times 10^{-10}$ \\
& 110 & Sand & 1.38 & 7.0 & - \\
& 15 & MS & 1.38 & 43.1 & - \\
& 38 & DM & 0.93 & 57.6 & $1.20 \times 10^{-9}$ \\
& 60 & DM & 0.96 & 56.7 & $2.74 \times 10^{-9}$ \\
& 85 & DM & 0.97 & 60.7 & - \\
\hline
\end{tabular}

Data $=$ average of 5-22 analyses; depth refers to middle of sampling cylinder

$w w$ wet weight, $M S$ marsh sediment, $D M$ dredged material, b.s. below surface
3. The third phase was characterised by seepage dynamics as shown in Fig. 5: Bottom fluxes in both test cells typically occurred in the late winter and in spring months whereas

Table 4 Selected chemical properties of solids and eluate of test cell materials, mixed sample over all layers

\begin{tabular}{|c|c|c|c|}
\hline Parameter & Unit & Marsh sediment & Dredged material \\
\hline \multicolumn{4}{|l|}{ Solids } \\
\hline $\mathrm{pH}$ in $\mathrm{H}_{2} \mathrm{O}$ & - & 6.6 & 7.6 \\
\hline Total organic carbon & mass- $\%$ & 1.9 & 4.3 \\
\hline Total nitrogen & mass- $\%$ & 0.19 & 0.40 \\
\hline Electric conductivity & $\mu \mathrm{S} \mathrm{cm}{ }^{-1}$ & 104 & 787 \\
\hline $\mathrm{Fe}$ & mass- $\%$ & 3.34 & 2.46 \\
\hline $\mathrm{Mn}$ & mass- $\%$ & 0.08 & 0.13 \\
\hline $\mathrm{S}$ & mass- $\%$ & 0.16 & 0.30 \\
\hline $\mathrm{Ca}$ & mass- $\%$ & 0.57 & 2.38 \\
\hline $\mathrm{Pb}$ & $\mathrm{mg} \mathrm{kg}^{-1}$ & 33.8 & 98.0 \\
\hline $\mathrm{Hg}$ & $\mathrm{mg} \mathrm{kg}^{-1}$ & 0.07 & 2.3 \\
\hline $\mathrm{Zn}$ & $\mathrm{mg} \mathrm{kg}^{-1}$ & 93.8 & 598.7 \\
\hline $\mathrm{Cu}$ & $m g ~ \mathrm{~kg}^{-1}$ & 30.6 & 128.0 \\
\hline $\mathrm{Cd}$ & $m g ~ \mathrm{~kg}^{-1}$ & 0.24 & 4.2 \\
\hline $\mathrm{Ni}$ & $\mathrm{mg} \mathrm{kg}^{-1}$ & 26.6 & 32.0 \\
\hline TBT & $\mu \mathrm{g} \mathrm{kg}^{-1}$ & 1.5 & 854 \\
\hline Sum $\mathrm{PCB}_{7}$ & $\mathrm{mg} \mathrm{kg}^{-1}$ & $<0.001$ & 0.0081 \\
\hline \multicolumn{4}{|l|}{ Eluate } \\
\hline $\mathrm{Cl}$ & $\operatorname{mg~} 1^{-1}$ & 1.6 & 8.6 \\
\hline Sulphate & $\operatorname{mg~} 1^{-1}$ & 14 & 249 \\
\hline $\mathrm{Pb}$ & $\operatorname{mg~} 1^{-1}$ & $<0.001$ & $<0.001$ \\
\hline $\mathrm{Hg}$ & $\operatorname{mg~} 1^{-1}$ & $<0.0002$ & $<0.0002$ \\
\hline $\mathrm{Zn}$ & $\operatorname{mg~} 1^{-1}$ & $<0.01$ & 0.17 \\
\hline $\mathrm{Cu}$ & $\operatorname{mg~} 1^{-1}$ & 0.0043 & 0.0051 \\
\hline $\mathrm{Cd}$ & $\operatorname{mg~} 1^{-1}$ & $<0.0003$ & 0.0015 \\
\hline $\mathrm{Ni}$ & $\mathrm{mg}^{-1}$ & 0.0041 & 0.017 \\
\hline Sum $\mathrm{PCB}_{7}$ & $\mu \mathrm{g}^{-1}$ & $<0.01$ & $<0.01$ \\
\hline
\end{tabular}

from mid-May to October no bottom fluxes were registered, except for events of summery torrential rains. The first part of this phase (mid-2008 to end of 2011) was characterised by an absence of storm tides, whereas the period thereafter was marked by one to two flood tides per year in the winter months.

The onset of discharge in fall was closely related to the preceding soil moisture status. In case of earlier high tides (e.g. on 9 Nov 2007, 5 Dec 2013, 30 Nov 2015) leading to increased soil moisture levels, both test cells reacted by a parallel increase in seepage rates beyond this point in time. If, however, high tides were absent during winter and the winter remained dry (e.g. 2008/2009: only $73 \mathrm{~mm}$ precipitation from November to January), the onset of discharge was delayed until February (test cell 2). In most cases, bottom

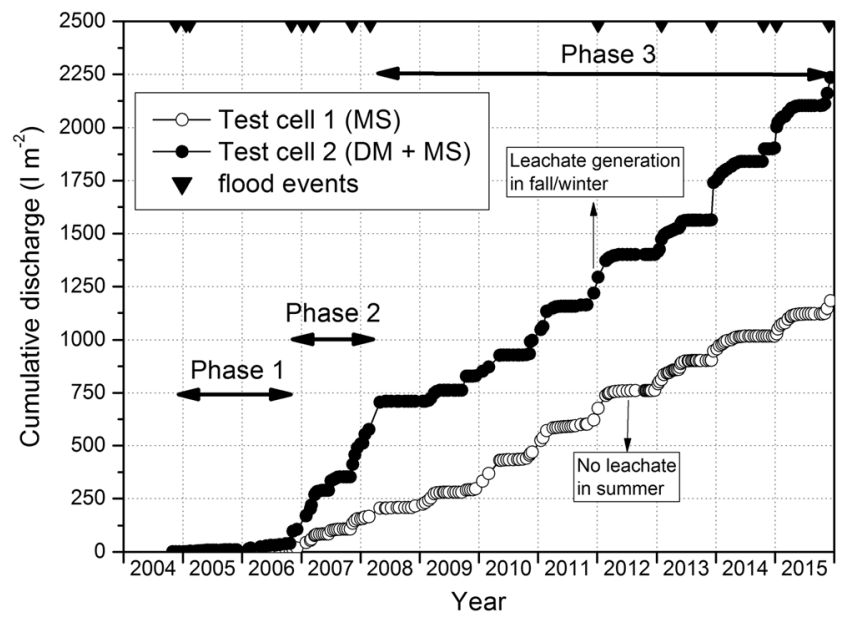

Fig. 4 Cumulative bottom flux from test cells in the period 2004-2015; data from inductive-magnetic flow meters in drainage shaft. Triangles mark flood events leading to a water level of $>3 \mathrm{~m}$ above mean sea level, hence exceeding the height of the lowest-lying point of the test cells (see Fig. 1) 
Fig. 5 Exemplary daily bottom flux from test cells over 1 year (2012-2013); data from water level loggers in measurement shaft

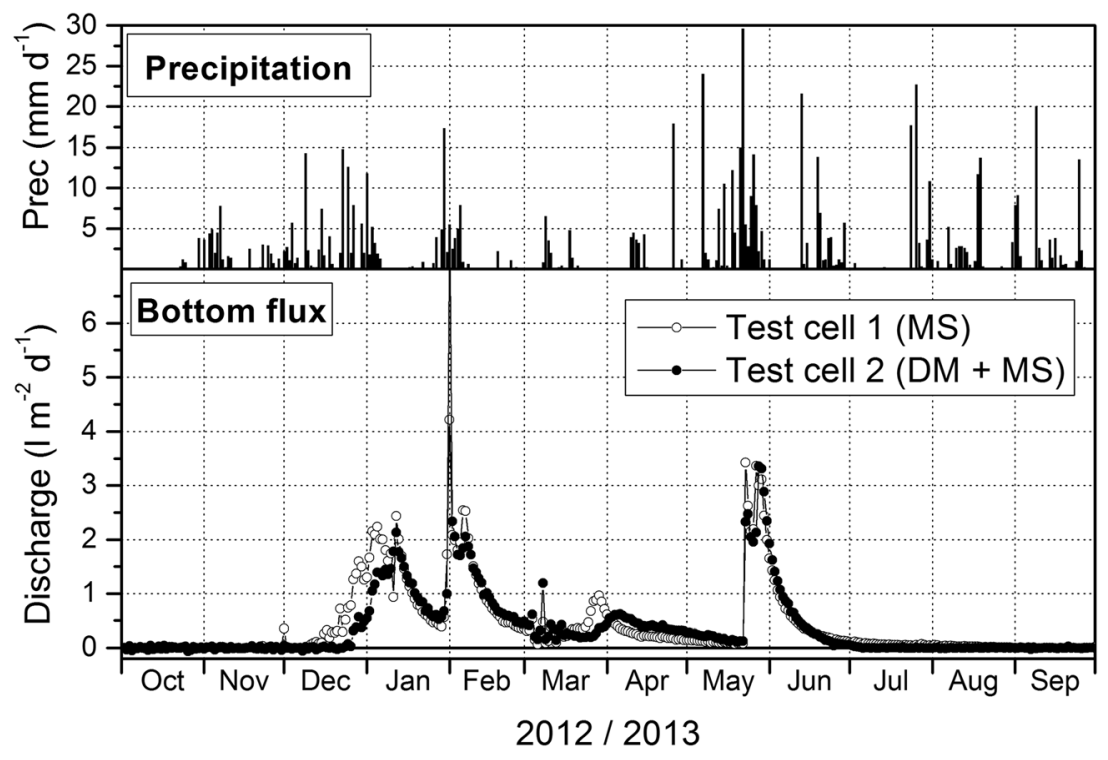

fluxes from test cell 2 were detected later in time than from test cell 1 , which is attributed to the higher water retention capacity (field capacity, pores $<50 \mu \mathrm{m}$ or water potential $>6 \mathrm{kPa}$ ) of the dredged material.

In the long term, the temporal discharge pattern of the two test cells was similar. Also, under conditions of normal hydraulic load (i.e. precipitation only), the magnitude of bottom fluxes was similar. The higher cumulative bottom flux from test cell 2, almost reaching a factor 2 by the end of 2015, was mainly related to increased seepage rates in the short phase 2 (20062008) and to increased discharge following events of higher hydraulic load due to flood events, indicating higher system hydraulic conductivity for test cell 2 (see Section 5.1.4).

\subsubsection{Reaction to precipitation: conditions of normal hydraulic load}

Figure 5 gives a more detailed view of the daily bottom flux as quantified from the water level readings in the collection chamber for the eighth year after construction (hence in the long-term phase 3), as well as on the concomitant course of precipitation. From the start of this period (October) to the beginning of December, no leachate was collected from either test cell in spite of the fact that precipitation amounted to $260 \mathrm{~mm}$. The start of leachate collection in December was 11 days earlier in test cell 1 (marsh sediment) than in test cell 2 (marsh sediment plus dredged material). In this phase, lasting until January 28, the difference in collected leachate volume was $171 \mathrm{~m}^{-2}$, indicating that the material in test cell 2 was able to retain more water before bottom flux started. Later in the winter season, at higher soil moisture levels, the test cells reacted to precipitation inputs with delayed outflow. Under these conditions, however, the bottom fluxes in both cells began at almost the same time.
The relationship between precipitation and daily discharges was examined using linear correlation analysis for the winter term, i.e. periods with lower evapotranspiration rates, but excluding periods with storm tides. Precipitation was reflected by the daily seepage rate with several days of attenuation in both test fields. This is seen from the fact that the coefficient of correlation between precipitation and discharge increased with increasing number of consecutive days over which precipitation was cumulated (Fig. 6). This dampening effect was observed to the same extent for both test cells, in spite of the fact that the system hydraulic conductivity was higher for the cell containing dredged material (Section 5.1.4) and that the soil structure featured continuous vertical primary shrinkage cracks in the dredged material (Section 5.3).

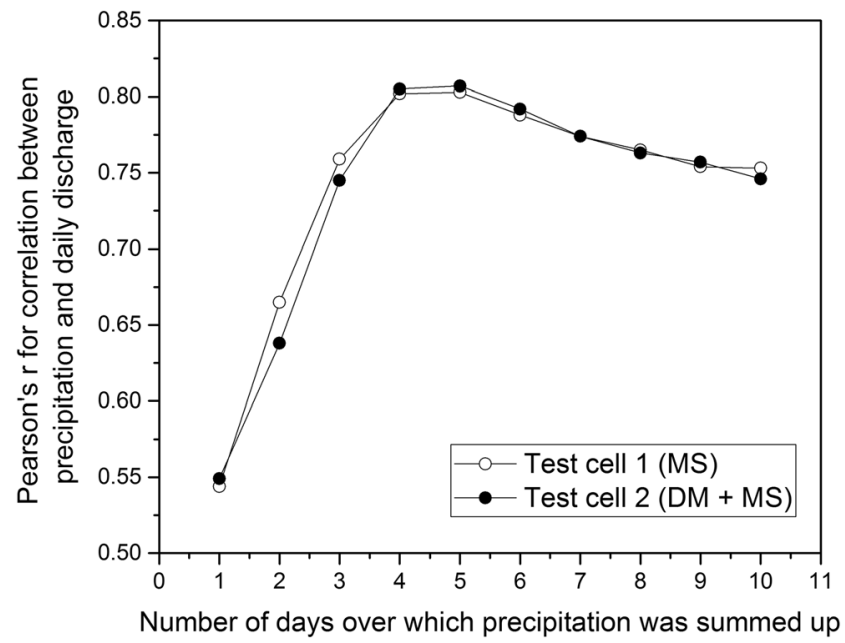

Fig. 6 Relationship between number of days over which precipitation was cumulated and the quality of correlation between cumulative precipitation and discharge measured on the day thereafter in the period 2013-2015. Data for winter periods without influence of storm tides and for conditions of full soil saturation. $n=219$ (cell 1) and $n=129$ (cell 2) 
The relatively high correlation coefficient of $>0.8$ between precipitation (cumulated over 5 days) and discharge (measured on day 6) shown in Fig. 6 should not mask the fact that the daily discharges scattered significantly with differences of up to $81 \mathrm{~m}^{-2}$ day $^{-1}$ if plotted against the cumulated discharge (data not shown). This is attributed to the fact that the actual seepage rates strongly depend on the prevailing capacity of the soil to retain water and hence on the water content at the respective point in time. If the seepage rates are quantitatively related to the precipitation cumulated over 5 days, it is seen that in fall and early winter periods in both test cells, only $5.9 \%$ (test cell 2) and $7.0 \%$ (test cell 1) of the precipitation reached the sand core as percolate, also due to the soil retaining the infiltrated water. Even in extended wet periods, when the water retention capacity of the soil was exhausted and volumetric soil water contents matched total porosity, only $32 \%$ (test cell 2 ) to $35 \%$ (test cell 1) of the precipitation reached the sand core as percolate. This indicates that when the water retention capacity of the dike cover was exceeded, around two thirds of the additional amount of precipitation left the system as surface runoff or interflow, hence not infiltrating into the sand core.

\subsubsection{Reaction to storm tides: conditions of enhanced hydraulic load}

As already suggested from Fig. 4, the discharge from the test cell containing dredged material increased more strongly under conditions of increased hydraulic load, for example during storm tide events, than the test cell constructed from marsh sediment only. Figure 7 focuses on such an event on 31 Jan 2013, caused by the storm front "Mark" over Central Europe. During this storm tide, the maximum Elbe water level reached a height of $0.43 \mathrm{~m}$ above the lower boundary of the

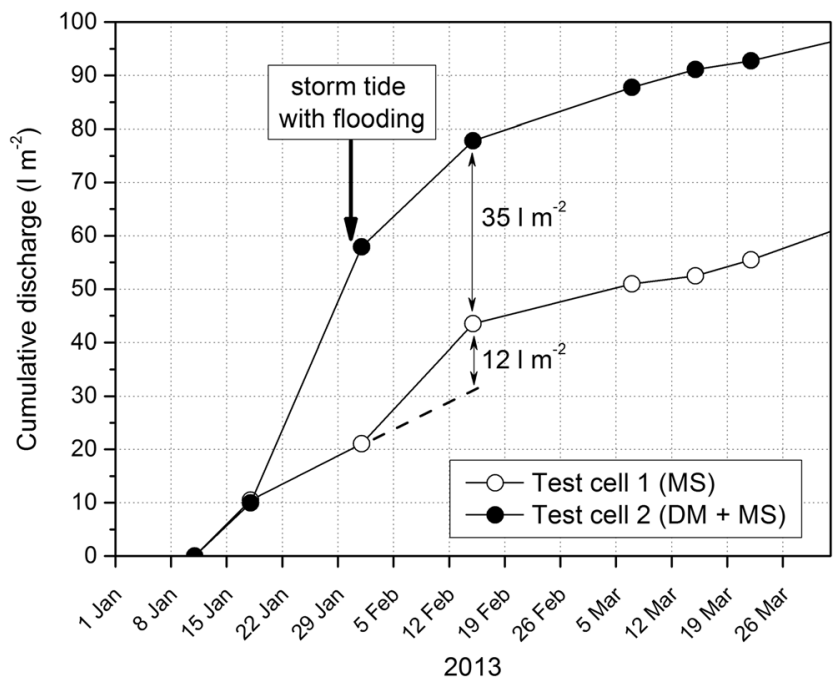

Fig. 7 Cumulative bottom flux from test cells during a storm tide event test cells and the lower parts of both fields were flooded for $140 \mathrm{~min}$.

In order to estimate the additional bottom flux resulting from the increased hydraulic load, the bottom flux was extrapolated from the flow rate measured before the event and compared to the flux that was measured during the storm tide (Fig. 7). For test cell 1 with marsh sediment only, an additional flux of $121 \mathrm{~m}^{-2}$ was calculated, and for test cell 2, containing the dredged material, an additional flux of $351 \mathrm{~m}^{-2}$ was derived, again pointing at increased system hydraulic conductivity of test cell 2.

\subsubsection{System hydraulic conductivity}

The hydraulic conductivity of the entire dike cover system, comprising all involved layers, was assessed for conditions of increased hydraulic load (i.e. storm tide events with water levels exceeding $4.3 \mathrm{~m}$ above mean sea level). For this analysis, the water level at the flood peak and the duration of flooding of the test cell, from the moment in time the lower test cell boundary was inundated to the moment the water left the lower test cell boundary, were used. From these, the hydraulic load on the test cells for conditions of storm tides was calculated using Eq. (1):

$\mathrm{HL}=\sum_{t_{i}}^{t_{e}} \mathrm{dt} * A * \frac{\frac{W}{2}+L}{L+0.3}$

with $\mathrm{HL}=$ hydraulic load $\left(\mathrm{m}^{2} \mathrm{~h}\right), A=$ flooded area $\left(\mathrm{m}^{2}\right), W=$ water level above lower test cell boundary $(\mathrm{cm}), L=$ depth of dike cover layer $(1.0 \mathrm{~m}), t_{i}=$ time begin of flooding, $t_{\mathrm{e}}=$ time end of flooding, $\mathrm{dt}=$ time interval $(1 / 6 \mathrm{~h})$.

The equation shows that the hydraulic head was normalised to a height of inundation of $0.3 \mathrm{~m}$ free water column, which, assuming saturated conditions within the dike, results in a total hydraulic gradient of $i=1.3$. The water level $W$ is divided by 2 to present the average hydraulic load over the flooded test cell area. The highest hydraulic load of the investigation period was determined for 6 Dec 2013 (6:02 a.m., data not shown), amounting to $242 \mathrm{~m}^{2} \mathrm{~h}$. Applying Eq. 1, the seepage rate (bottom flux) under these conditions corresponds to the seepage from an area of $242 \mathrm{~m}^{2}$ that is inundated for the duration of $1 \mathrm{~h}$ with a water table of $30 \mathrm{~cm}$ height. It is seen that the system hydraulic conductivity varied significantly. In most cases, but not always, the system hydraulic conductivity was higher for test cell 2 , containing the dredged material, than for test cell 1 (marsh sediment only).

\subsection{Leachate composition}

Leachate composition is indicative of soil structure development. Conservative tracers that are non-reactive and do not 
adsorb to the soil matrix, such as chloride, mark leachate pathways and allow separating different leachate sources whereas redox-sensitive species such as ammonium indicate changes in the extent of aeration of the soil due to soil structure development. Leachate omposition was monitored closely in the first five years after test cell construction. After this point, the measurement of leachate qauntity continued, but monitoring of quality was terminated and only resumed in 2013.

Chloride concentrations in the leachate of test cell 2 showed a steady decline until they stabilised on the level of the chloride content of leachate from test cell 1 (Fig. 8a). Dredged material contains more chloride than the marsh sediment (see also Table 3), resulting from its origin as sediment from the Elbe river (chloride concentrations vary around $150 \mathrm{mg} \mathrm{l}^{-1}$ ). The decline indicates progressive extrusion of the original pore water and concurrent desalination of the material by percolation with rainwater. The high initial concentration of chloride in the test cell 1 leachate, which was rapidly declining, reflects initial leaching of water from the drainage sand, itself a product from processed dredged Elbe river sediment, not from the marsh sediment. Spiking concentrations can either be due to 'first flush' effects, i.e. elution of pore water constituents that have accumulated during dry periods or due to flooding, re-introducing riverwater with elevated chloride concentrations.

Corresponding to its organic matter content of up to $10 \%$, the dredged material contains quite some nitrogen (Table 3), which under anaerobic conditions is mineralised as ammonium and accumulated when the hydraulic conductivity is low. Until the summer of 2006, almost two years after construction, ammonium contents in test cell 2 leachate continued to increase, indicating progressive anaerobic mineralisation of organic matter, but then abruptly dropped to zero and thereafter remained non-detectable (Fig. 8b). Concurrently, release of nitrogen as nitrate (Fig. 8c) and a marked increase in sulphate concentrations were observed (Fig. 8d). Soluble iron was only
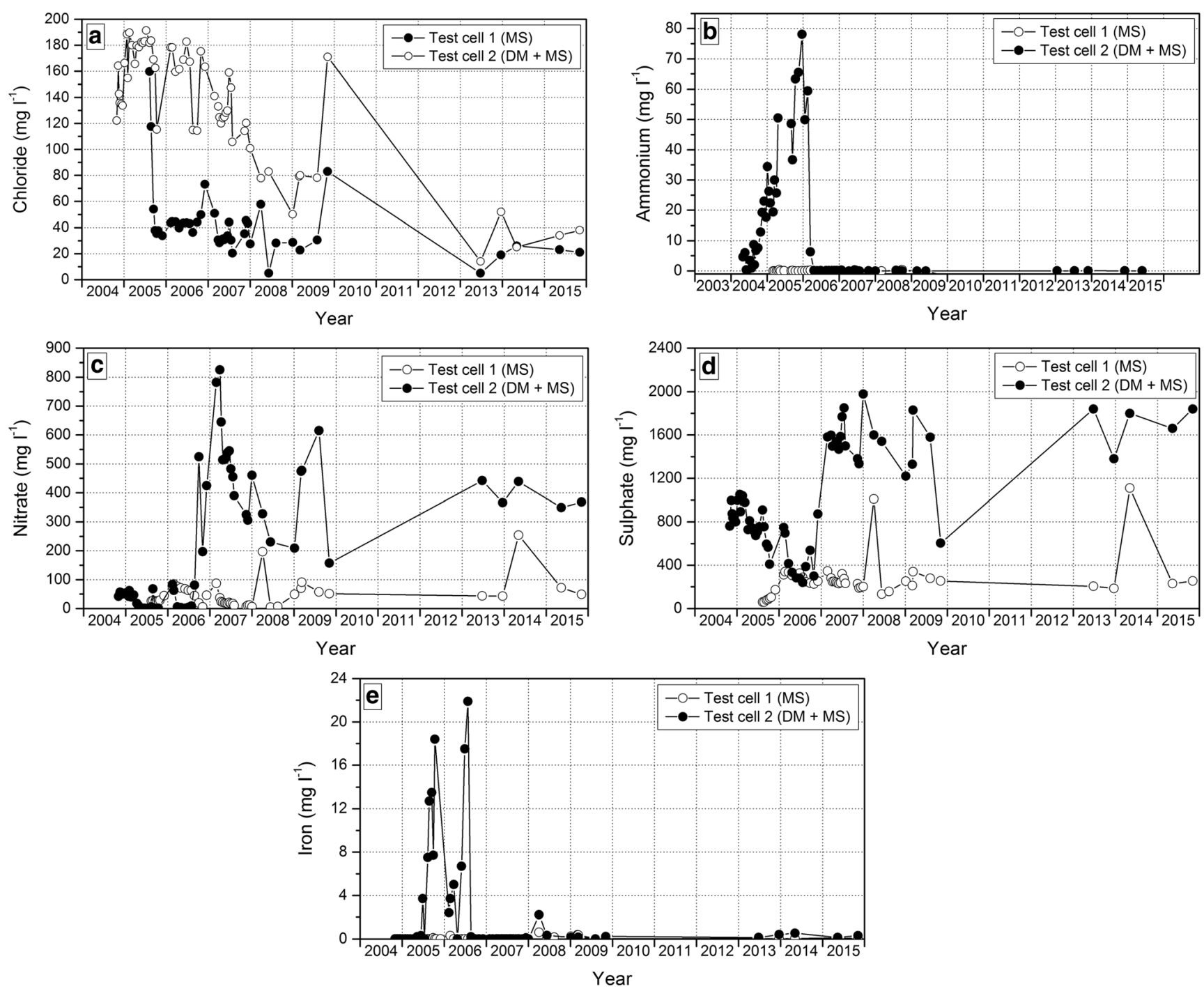

Fig. 8 Concentration of selected components of test cell leachate over time. MS = marsh sediment, DM=dredged material 
detected in the initial phase in which also ammonium was found (Fig. 8e). By contrast, nitrogen and sulphate contents in the leachate from test cell 1 did not follow a particular pattern; ammonium and soluble iron were never detected.

\subsection{Development of soil structure}

In 2012, eight years after construction, the soils adjacent to each test cell (same setup, but outside of the collection pan) were excavated to investigate the soil structure that had developed under the influence of vegetation, climate and flooding (Fig. 9). Field analysis of the soil profile in test cell 2 (marsh sediment + dredged material, Fig. 9, right panel) revealed that the top layer from marsh sediment was intensively penetrated by fine roots, slightly enriched with humus and showed a crumbly to sub-angular blocky structure. Aggregate surfaces were characterised by marked redoximorphic discolouration, suggesting sporadic presence of impounding water. The layer changeover to the dredged material in about $30 \mathrm{~cm}$ depth was clearly visible. The dredged material showed a columnar structure over its entire depth with straight vertical tensile cracks of greater than $1 \mathrm{~cm}$ width occurring in a distinct spatial pattern of about $20 \mathrm{~cm}$ distance, resulting from shrinkage of the dredged material. These primary cracks were not re-filled with material from above. Within the columns, the dredged material was structured by sub-angular blocky aggregates. Fine roots were found down to a depth of $1 \mathrm{~m}$. The soil matrix was coloured homogeneously grey without indications of impounding water. Especially in the upper part, the cracked surfaces were darkly coated, presumably due to the elution of manganese mobilised from the overlying marsh sediment layer under conditions of low redox potential.
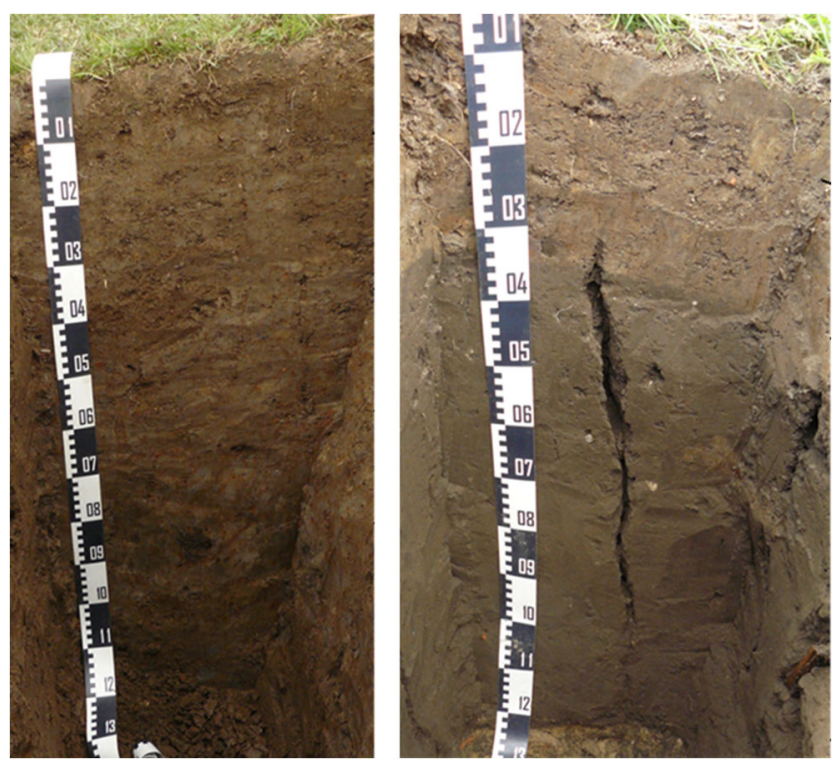

Fig. 9 Soil profile view of test cell 1 (left, marsh sediment) and test cell 2 (right, marsh sediment + dredged material), excavated in 2012, eight years after construction
The marsh sediment in test cell 1 (marsh sediment only, Fig. 9 left panel) featured a sub-angular blocky aggregate structure in the top $45 \mathrm{~cm}$, below which the soil matrix was more or less coherent and corresponding to the conditions at construction. Cracks resulting from tensile stresses acting on a larger scale were absent. As in the top layer of test cell 2, redoximorphic discolourations were visible, mainly in the upper part, which are indicative of temporary conditions of saturation.

\section{Discussion}

The in situ measurements of the seepage rate and quality through the covers of two experimental dike test cells allowed the comparison of the hydraulic behaviour of two dike test cells, one of which was partly substituted with treated dredged material while the other one was constructed from the traditionally used clayey marsh soil. Conditions of "normal" hydraulic load (water supply by precipitation only) could be distinguished from conditions of hydraulic pressure (storm tides). In general, seepage rates are controlled by the interactions between soil, vegetation and soil organisms and their direct or indirect influence on the movement of water through the soil. The measured flow rates and the composition of the seepage are an indicator for soil structuring processes and the development of the vegetation of the studied dike segments.

In phase 1 (i.e. in the first two years after construction, Fig. 4), low leachate rates were observed. Both cover materials maintained the low initial hydraulic conductivities achieved by the compacting construction practice $\left(<2.8 \times 10^{-9} \mathrm{~m} \mathrm{~s}^{-1}\right.$, Table 2). For the dredged material, these values were in the range as found for the construction of mineral liners of landfills (Tresselt 2000; Berger et al. 2019). The hydraulic conductivity of the marsh sediment was even lower. Although in the first winter the climatic water balance showed a surplus of $1601 \mathrm{~m}^{-2}$, no bottom flux could be collected due to this low hydraulic conductivity. Also, surface runoff must have occurred (not measured). After construction and due to compaction, both the marsh sediment and the dredged material were under nearly water-saturated conditions. The low but detectable occurring bottom fluxes of test cell 2 in the first phase can be explained by self-consolidation of the material, leading to the according loss of pore water.

The excavation in 2012 revealed increased dry bulk densities of 1.02 to $1.13 \mathrm{~g} \mathrm{~cm}^{-3}$ (average $1.092 \mathrm{~g} \mathrm{~cm}^{-3}$; Gröngröft et al. 2013), compared to 0.93 to $0.97 \mathrm{~g} \mathrm{~cm}^{-3}$ at the time of construction (Table 3 ). The high concentrations of ammonium in the seepage indicated anaerobic conditions in the dredged material in this phase (Fig. 7b). The growing vegetation with its expanding root system transpired large amounts of water stored in the cover layers. The pore size analysis (Table 2) showed that the amount of plant-available water was about 
twice as high in the test cell constructed with dredged material (about $3001 \mathrm{~m}^{-2}$ in $1 \mathrm{~m}$ depth) compared to the test cell constructed with pure marsh sediments.

In phase 2, seepage rates showed a marked increase, especially in the test cell with dredged material. Concomitantly, concentrations of ammonium and soluble iron plummeted to zero, while those of nitrate and sulphate increased, indicating the changeover from reducing to oxidizing conditions, which were never again reversed. For the period of 2004 to 2008, the most negative climatic hydrological balance of $-185 \mathrm{~mm}$ was observed for the year 2006 (months April to September, data from the German Weather Service, DWD). It is assumed that in this dry summer of 2006, 2 years after construction, the roots of the grassy vegetation tapped the dredged material. In combination with capillary rise, this led to dewatering and irreversible primary shrinkage which in turn caused the marked increase in seepage rates. Shrinkage of the marsh sediment cover layer, reversible though, was easily visible from the soil surface.

The long-term and still ongoing phase 3 is characterised by a similar hydraulic behaviour of both test cells, exhibiting a clear seasonal pattern of bottom fluxes with little to no leachate collected during summer and increased seepage during fall and winter. In test cell 1, leachate collection usually started earlier than in test cell 2, which, however, showed slightly higher seepage rates (Fig. 5). This is assumed to be due to two effects: the higher water storage capacity of the test field constructed from dredged material results in a longer phase of water uptake at the beginning of the winter season. If the water content is equilibrated, then the higher hydraulic conductivity of this cover leads to larger amounts of seepage. However, the differences between both cover systems are levelled by the fact that the top $30 \mathrm{~cm}$ layer of both cells consist of marsh sediment, the shrinking and swelling status of which governs infiltration into the underlying body of dredged material.
There was no direct relationship between daily precipitation and leachate generation, but between precipitation cumulated over 5 days and the discharge measured on day 6 . Increased bottom fluxes were observed from test cell 2 under conditions of higher hydraulic load (Fig. 6). In line with the observed irreversible cracks formed during initial dewatering, the hydraulic conductivity of the setup with the dredged material was about one order of magnitude lower under conditions of higher load (Table 5).

For the dredged material, the structural development as initiated by the loss of water through evapotranspiration two years after construction marked the onset of the processes of soil ripening. These have been previously described for cases of embankment of sediments for land reclamation (Pons and Zonneveld 1965; Vermeulen et al. 2003). Irreversible shrinkage led to the development of permanent vertical cracks of 1-2 cm thickness (Fig. 8). Laboratory shrinkage tests, carried out on the dredged material in mesocosms, revealed a shrinkage of $10 \%$ of the original volume to be irreversible, while another $5 \%$ were reversible (Oing 2018). The marsh sediment, on the other hand, had undergone the processes of soil ripening at its original natural location. The shrink-swell behaviour was hence fully reversible with cracks formed in the summery dry season typically closing upon wetting during autumn and winter. During physical ripening, the soil structure forms as a result of repeated cycles of drying and wetting, leading to shrinkage and reswelling. Thereby, pasty, anaerobic (reduced) sediment is transformed to a consolidated, well-structured (aggregated) and aerated (aerobic, oxidised) soil. Subsequently, physical properties such as hydraulic conductivity or air permeability undergo great changes.

Following dewatering and shrinkage, the intrusion of atmospheric air into the dredged material triggered the changeover
Table 5 Calculated hydraulic conductivities for the entire system setup under conditions of increased load (storm tides)

\begin{tabular}{|c|c|c|c|c|}
\hline Date of storm tide & Test cell & $\begin{array}{l}\text { Hydraulic } \\
\text { load }\left(\mathrm{m}^{2} \mathrm{~h}\right)\end{array}$ & $\begin{array}{l}\text { Bottom } \\
\text { flux }\left(\mathrm{m}^{3}\right)\end{array}$ & $\begin{array}{l}\text { System hydraulic } \\
\text { conductivity }\left(\mathrm{m} \mathrm{s}^{-1}\right)\end{array}$ \\
\hline \multirow[t]{2}{*}{6 Jan 2012} & 1 (MS) & 0.17 & 0.00 & - \\
\hline & $2(\mathrm{MS}+\mathrm{DM})$ & 0.17 & 3.58 & $4.4 \times 10^{-3}$ \\
\hline \multirow[t]{2}{*}{31 Jan 2013} & $1(\mathrm{MS})$ & 17.12 & 0.00 & - \\
\hline & $2(\mathrm{MS}+\mathrm{DM})$ & 16.91 & 3.96 & $5.0 \times 10^{-5}$ \\
\hline \multirow[t]{2}{*}{5 Dec 2013} & $1(\mathrm{MS})$ & 0.28 & 0.802 & $6.1 \times 10^{-4}$ \\
\hline & $2(\mathrm{MS}+\mathrm{DM})$ & 0.28 & 0.580 & $4.4 \times 10^{-4}$ \\
\hline 1 st storm tide & $1(\mathrm{MS})$ & 241.71 & 1.952 & $1.7 \times 10^{-6}$ \\
\hline 6 Dec 2013 & $2(\mathrm{MS}+\mathrm{DM})$ & 238.84 & 11.25 & $1.0 \times 10^{-5}$ \\
\hline 2nd storm tide & $1(\mathrm{MS})$ & 33.19 & 0.00 & - \\
\hline 6 Dec. 2013 & $2(\mathrm{MS}+\mathrm{DM})$ & 32.80 & 3.00 & $1.9 \times 10^{-5}$ \\
\hline \multirow[t]{2}{*}{11 Jan 2015} & $1(\mathrm{MS})$ & 44.57 & 0.24 & $1.1 \times 10^{-6}$ \\
\hline & $2(\mathrm{MS}+\mathrm{DM})$ & 45.04 & 10.83 & $5.1 \times 10^{-5}$ \\
\hline 30 Nov 2015 & $2(\mathrm{MS}+\mathrm{DM})$ & 15.23 & 3.92 & $5.5 \times 10^{-5}$ \\
\hline
\end{tabular}


from anaerobic to aerobic conditions and gave rise to a variety of geochemical transformations as part of the chemical ripening of the soil (Fig. 7). The changeover is marked by a sharp decrease in ammonium produced during anaerobic decomposition of organic matter, the decrease in soluble iron and manganese (not shown) and the corresponding increase in nitrate as a result of aerobic turnover of organic matter and in sulphate, released from formerly reduced sulphur components. Coatings of manganese precipitates were seen on crack surfaces. Biological soil ripening is promoted by plant roots and microbial degradation and mineralisation of organic matter. Plant rooting in turn enhances dewatering of the material, directly contributing to aggregation of particles and hence soil structure formation.

\section{Conclusions}

Twelve years of investigation of a dike section in which the lower $70 \mathrm{~cm}$ of the cover soil had been substituted by treated dredged material showed that the construction was physically stable (i.e. was not eroded and did not fail) under all climatic conditions encountered in this period, including summery desiccation, flooding by storm tides and ice drift. The combination of measurements of leachate volume and leachate compositions allowed the identification of the timely course of physical and chemical soil ripening processes, earmarked by the establishment of distinctive seasonal discharge patterns and the changeover from reducing to oxidising conditions. Long-term hydraulic behaviour was governed by the infiltration capacity of the top layer of marsh sediment; the high storage capacity of the dredged material for plant-available water, leading to a delayed onset of discharge in the wet season; and the material's increased hydraulic conductivity due to the vertical cracks caused by primary shrinkage. This, however, did not impair the dike's functionality in the investigation period, which included events of desiccation, storm tides and ice drift. To assure the positive assessment of the use of dredged material in dike covers, an analysis of the expectable long-term hydraulic stresses is recommended.

Physical and subsequent chemical soil ripening occurred after the material was already in place, within the dike body. In order to prevent primary shrinkage and subsequent formation of irreversible cracks to occur in situ, it should be investigated whether the material can be dewatered to moisture contents below which primary shrinkage terminates, also allowing for higher levels of compaction to be reached during construction. This could be achieved by higher dewatering intensities in the sediment treatment plants (such as the German METHA or the Belgian AMORAS plant) or by shallower flushing layers and increased frequency of heap turning in the case of treatment of dredged material in dewatering fields, such as in the Dutch Kleirijperij pilot plant.
Further, the use of vegetation to enhance dewatering by means of transpiration could be investigated. Use of contaminated dredged material in dike construction requires an assessment of the potential mobilisation and emission of contaminants.

Funding information This study was funded by Hamburg Port Authority.

Open Access This article is licensed under a Creative Commons Attribution 4.0 International License, which permits use, sharing, adaptation, distribution and reproduction in any medium or format, as long as you give appropriate credit to the original author(s) and the source, provide a link to the Creative Commons licence, and indicate if changes were made. The images or other third party material in this article are included in the article's Creative Commons licence, unless indicated otherwise in a credit line to the material. If material is not included in the article's Creative Commons licence and your intended use is not permitted by statutory regulation or exceeds the permitted use, you will need to obtain permission directly from the copyright holder. To view a copy of this licence, visit http://creativecommons.org/licenses/by/4.0/.

\section{References}

Ausschuss für Küstenschutzwerke (2002) Empfehlungen für die Ausführung von Küstenschutzwerken (EAK). Westholsteinische Verlagsanstalt u. Verlagsdruckerei Boyens GmbH \& Co. KG

Baptist MJ, Gerkema T, van Prooijen BC, van Maren DS, van Regteren M, Schulz K, Colosimo I, Vroom J, van Kessel T, Grasmeijer B, Willemsen P, Elschot K, de Groot AV, Cleveringa J, van Eekelen EMM, Schuurman F, de Lange HJ, van Puijenbroek MEB (2019) Beneficial use of dredged sediment to enhance salt marsh development by applying a 'mud motor'. Ecol Eng 127:312-323

Berger K, Groengroeft A, Gebert J (2019) 20 years performance measurements of a landfill cover system with components constructed from pre-treated dredged sediments. Waste Manag 100:230-239

Bortone G, Palumbo L (eds) (2007) Sednet: "sediment and dredged material treatment", sustainable management of sediment resources, vol 2. Elsevier, Amsterdam, The Netherlands

Cappuyns V, Deweirt V, Rousseeau S (2015) Dredged sediments as a resource for brick production: possibilities and barriers from a consumers' perspective. Waste Manag 38:372-380

CEDA (2019) Sustainable management of the beneficial use of sediments. Information paper. Available from https://dredging.org/ media/ceda/org/documents/ceda/2019-05-bus-ip.pdf. Accessed 17 Dec 2019

Detzner HD, Schramm W, Döring U, Bode W (1997) New technology of mechanical treatment of dredged material from Hamburg harbour. In: Calmano $\mathrm{W}$ et al (eds) Proceedings of the International Conference on Contaminated Sediments, 7.-11.9.1997, Rotterdam, pp 267-274

DWA-Arbeitsgruppe WW-7.3 (ed) (2005) Dichtungssysteme in Deichen. DWA-Themen. Hennef: DWA, $44 \mathrm{~S}$

FAO, Food and Agriculture Organization of the United Nations (2006) Guidelines for Soil Description. ISBN 92-5-105521-1

Gröngröft A, Streblow C, Eschenbach A (2013) Wissenschaftliche Untersuchungen von Testfeldern zur Eignung von Baggergut im Deichbau: Strukturentwicklung des Deichbaumaterials. Unpublished report to Hamburg Port Authority (in German)

Gutbrod J (2016) Herrichtung Logistikfläche Dradenau - Verwertung von METHA-Material bei der Flächenaufhöhung. Tagungsband zum 9. Rostocker Baggergutseminar, Steinbeis-Transferzentrum 
Angewandte Landschaftsplanung (Universität Rostock), ISBN 9783-95872-036-7 (in German)

LAGA Ad-hoc-AG "Deponietechnische Vollzugsfragen" (2008) Eignungsbeurteilung von METHA-Material zur Herstellung von mineralischen Dichtungen (Suitability assessment of METHAMaterial for the construction of mineral sealing). Available from: http://www.gewerbeaufsicht.niedersachsen.de/download/30121/ Eignungsbeurteilung von METHA-Material zur Herstellung von_mineralischen_Dichtungen.pdf. Accessed 17 Dec 2019. (in German)

Oing K (2018) Suitability of processed dredged material from the Hamburg harbor for dike construction. Dissertation. Hamburg Soil Science Studies, ISSN 0724-6382

OSPAR (2016) OSPAR annual report on dumping and placement of wastes or other matter at sea in 2014. ISBN: 978-1-911458-01-2. Publication number: 671/2016
Pons LJ, Zonneveld I (1965) Soil ripening and soil classification: initial soil formation of alluvial deposits with a classification of the resulting soils. Wageningen, Netherlands, H. Veenman

Saathoff F, Cantré S, Sikora Z (eds) (2013) South Baltic guideline for the application of dredged materials, coal combustion products and geosynthetics in dike construction. http://www.dredgdikes.eu/wpcontent/uploads/DredgDikes_guideline_EN_online.pdf. Accessed 17 Dec 2019

Tresselt K (2000) Feldversuche zur Wirksamkeit von Oberflächendichtungssystemen mit Dichtungen aus Hafenschlick. Dissertation Hamburg Soil Science Studies 46, ISSN 0724-6382

Vermeulen J, Grotenhuis T, Joziasse J, Rulkens W (2003) Ripening of clayey dredged sediments during temporary upland disposal a bioremediation technique. J Soils Sediments 3:49-59

Publisher's note Springer Nature remains neutral with regard to jurisdictional claims in published maps and institutional affiliations. 